\title{
EVALUASI PROGRAM PRAKTEK KERJA INDUSTRI DI SMK SARASWATI SALATIGA
}

\author{
Tarmidi $^{1}$, Wasitohadi ${ }^{2}$, Bambang Ismanto ${ }^{3}$ \\ ${ }^{1,2,3}$ Universitas Kristen Satya Wacana \\ e-mail: tarmidi907@gmail.com ${ }^{1}$, wasitohadi@staff.uksw.edu ${ }^{2}$, \\ bambang.ismanto@uksw.edu ${ }^{3}$
}

\begin{abstract}
Abstrak
Penelitian di SMK Saraswati Salatiga dilakukan untuk menjawab beberapa pertanyaan: 1) Bagaimana evaluasi konteks Prakerin di SMK Saraswati Salatiga?; 2) Bagaimana evaluasi program Input Prakerin di SMK Saraswati Salatiga?; 3) Bagaimana proses evaluasi program Prakerin di SMK Saraswati Salatiga?; 4) bagaimana cara mengevaluasi produk dari kegiatan Prakerin di SMK Saraswati Salatiga. Penelitian ini menggunakan CIPP sebagai metode penelitian. Teknik yang digunakan untuk mengumpulkan data meliputi, observasi, wawancara dan dokumentasi. Evaluasi data menggunakan metode dan teknik triangulasi sumber. Teknik analisis data dilakukan mulai dari proses pengumpulan data, reduksi data, penyajian data, dan variasi yang disajikan secara deskriptif kualitatif. Hasil penelitian menunjukkan visi dan misi telah dielaborasi dalam perumusan kompetensi lulusan. Tujuan prakerin telah diimplementasikan dengan breed, tetapi masih ada kekurangan. Pembentukan Kurikulum Sekolah Kejuruan Saraswati telah melibatkan Industri. teknik implementasi, prosedur penempatan siswa, jadwal dan manajemen anggaran sesuai dengan prosedur yang ditetapkan. Implementasi program magang telah dilakukan dengan baik, hanya saja pemantauan guru pembimbing perlu ditingkatkan. Produk-produk dari program pra-program menunjukkan prestasi dalam kategori baik, manfaat magang dapat dirasakan oleh semua pemangku kepentingan mulai dari industri, sekolah hingga siswa. Untuk evaluasi kegiatan pemagangan yang sudah dilakukan, ada yang masih kurang
\end{abstract}

Kata kunci : Evaluasi, Prakerin, CIPP

\begin{abstract}
Research at SMK Saraswati Salatiga was conducted to answer some questions: 1) How is the evaluation of the Prakerin context at SMK Saraswati Salatiga ?; 2) How is the evaluation of the Prakerin Input program at SMK Saraswati Salatiga?; 3) How is the evaluation process of the Prakerin program at SMK Saraswati Salatiga?; 4) how to evaluate products from Prakerin activities at SMK Saraswati Salatiga. This study uses the CIPP as a research method. Techniques used to collect data include, observation, interviews and documentation. Data evaluation used source triangulation methods and techniques. Data analysis techniques were carried out starting from the process of data collection, data reduction, data presentation, and variation that were presented in a descriptive qualitative manner. The results showed the vision and mission had been elaborated in the formulation of graduate competencies. Prakerin objectives have been implemented with breed, but there are still shortcomings. The formation of the Saraswati Vocational School Curriculum has involved the Industry. implementation techniques, student placement procedures, schedule and budget management are in accordance with established procedures. The implementation of the internship program has been carried out well, it's just that the monitoring of the supervising teacher needs to be improved. The products of the pre-program program show achievements in the good category, the benefits of the apprenticeship can be felt by all stekeholders ranging from industry, schools to students. For the evaluation of the apprenticeship activities already carried out, some are still lacking
\end{abstract}

Keywords : Evaluation, Prakerin, CIPP 


\section{PENDAHULUAN}

Menurut UU No 20 tahun 2003 SMK merupakan pendidikan menengah yang tujuannya adalah menyiapkan peserta didik agar dapat bekerja sesuai dengan kompetensi bidangnya masing-masing. Oleh karenanya SMK harus membekali peserta didik dengan kompetensi sesuai dengan kebutuhan dunia kerja. Namun faktanya SMK masih belum mampu menyediakan tenaga kerja sesuai dengan kebutuhan Dunia Usaha atau Dunia Industri. Berdasarkan data yang diperoleh BPS pada bulan Februari 2019 lulusan SMK paling banyak menyumbang penganggurn, sebanyak $8,63 \%$ dari 136,18 juta orang atau sebanyak 11. 752 . 334 Orang. Walaupun itu lebih baik jika dibandingkan pada tahun 2018 yaitu sebanyak $8,92 \%$ yaitu berkurang sebanyak 0,39\%. Hal tersebut menjelaskan bahwa tujuan SMK belum tercapai dengan baik. Berdasarkan paparan yang ditulis pada rencana Kemendikbud Tahun 2015-2019 Nilai tersebut dikarenakan relevansi kebutuhan DU/DI dengan lulusan SMK masih rendah. Oleh karenanya diperlukanlangkah strategi agar kompetensi peserta didik dapat meningkat mendekati kebutuhan Industri. salah satu langkah yang dapat dilaksanakan adalah memaksimalkan program yang dapat meningkatkan kompetensi peserta didik sesuai dengan kebutuhan DU/DI. Program paling efektif sebagai jembatan antra Sekolahan dan DU/DI adalah Praktik Kerja Industri. Karena dengan mengikuti Program prakerin peserta didik akan mendapat pengalaman bekerja secara langsung sesuai dengan kompetensi di tempat kerja yang semestinya. Manfaat lain yang didapat peserta didik adalah mereka dapat melihat sejauh mana kompetensinya dengan kebutuhan Industri saat ini. Sehingga setelah program selesai diharapkan merubah sudut pandang dan perilaku peserta didik mengenai Dunia Usaha atau Duni Industri.

Hamalik (2001:91) menjelaskan

Praktek Kerja Industri (Prakeirn) merupakan program pembelajaran yang dilakukan peserta didik secara langsung dilapangan. Berdasarkan pedoman Prakerin dikmenjur (2018:5). Wardiman Djojonegoro (1998:79) menjelaskan bahwa prakerin merupakan bentuk dari kompetensi keahlian yang ada di sekolah secara terpadu bersama Dunia Usaha Dunia Industri (DU/DI) agar peserta didik mendapat keahlian secara profesional. Sedangkan menurut Oemar Hamalik (2007:21) menjelaskan bahwa On the Job Training atau OJT adalah model pelatihan yang dilaksanakan di lapangan, yang bertujuan untuk memberikan keterampilan tertentu sesuai dengan kebutuhan kemampuan pekerjaan. Program tersebut sangat bermanfaat bagi peserta didik. tujuan dari program tersebut adalah 1) memberikan pengalaman kerja kepada peserta didik untuk menanamkan iklim kerja positif; 2) membangun dan mengembangkan kepribadian yang peserta didik sesuai dengan kebutuhan masyarakat, khususnya DU/DI; 3) menanamkan etos kerja kepada peserta didik sebagai bekal memasuki dunia kerja sesuai dengan tuntutan pasar kerja global; 4) sebagai pelengkap materi yang belum tersampaikan di sekolah; 5) Mengaktualisasikan salah satu bentuk aktivitas dalam penyelenggaraan Model Pendidikan Sistem Ganda (PSG) antara SMK dan Institusi Pasangan yang memadukan secara sistematis dan sistemik program pendidikan di sekolah (SMK) dan program pelatihan penguasaan keahlian di dunia kerja (DUDI). Menurut pedoman pelaksanaan prakerin SMK Saraswati Salatiga tujuan program prakerin adalah untuk memberikan pengalaman kerja langsung untuk menanamkan iklim kerja positif yang berorientasi pada mutu dan hasil kerja. Menumbuh kembangkan etos kerja bagi peserta didik agar siap memasuki dunai kerja. Memenuhi hal yang belum tersampaikan di sekolah agar tercapai kebutuhan standar kompetensi lulusan. Sebagai bentuk aktualisasi pendidikan dan Dunia Usaha atau Dunia Industri. sebagai paduan sistem pendidikan SMK dan program pelatihan di Dunia Kerja. Manfaat prakerin menurut Depdiknas (2013:105) antara lain: 1) menyadarkan peserta didik bahwa dalam keterampilan tidak hanya Soft Skill akan tetapi bertujuan untuk penerapan pengetahuan secara langsung ilmu yang didapat disekolah. 2) sebagai bentuk latihan sekaligus praktik yang dilakukan yang dilakukan secara mendasar; 3) membantu peningkatan kesejahteraan dalam bentuk fasilitas dan biaya operasional SMK; 4) menumbuh kembangkan enterpreneurhsip guru dan peserta didik; 5) mengembangkan kepercayaan diri dan kemandirian melalui kegiatan produksi; 6) Mejalin hubungan baik antara dunia Usaha atau Dunia Industri dan juga masyarakat. Sedangkan bagi sekolah, sekolah mendapat kerja sama dengan industri dalam mengembangakan kompetensi peserta didik. sehingga sekolahan akan terbantu dalam menyiapkan tenaga kerja yang profesional dalam bidangnya. Sedangkan manfaat yang diperoleh Industri dari kegiatan prakerin ini 
adalah sebagai bahan evaluasi bagi kegiatan prakerin yang akan dilakukan mendatang.

Menurut Dikmenjur (2008:12) Prakerin dilaksanakan berdasarkan silabus yang diimplementasikan ke dalam pembelajaran yang telah direncanakan dari kegiatan prakerin. Dalam penyusunannya membuthkan metode, strategi dan evaluasi yang dilasanakan secara selaras. Pelaksanaan program prakerin perlu memperhatikan kesiapan dari industri sebagai mitra sekolah. Hal ini dilakukan agar dalam penempatan pekserta didik tepat sasaran dan sesuai dengan kompetensi keahlian peserta didik.

Tahapan awal prakerin dimulai dengan penyusunan program yang dilakukan oleh kepala sekolah, ketua Humas, Kepala Jurusan dan Dunia Usaha atau Dunia Industri. Penyusunan program prakerin bertujuan untuk menentukan jenis kegiatan yang akan dilakukan selama peserta didik mengikuti program prakerin. Hal tersbut sekaligus menjadi dasar pedoman pelaksanan prakerin bagi peserta didik. Dikmenjur (2008:12) menjelaskan ada tiga model yang dapat digunakan antara lain: 1) Day Release model ini dilaksakan dengan cara sehari peserta didik di sekolahan hari berikutnya mereka di tempat DU/DI; 2) Weak Release model ini peserta didik akan belajar seminggu di sekolahan kemudian seminggu belajar di DU/DI; 3) Blok Release merupakan bentuk pembelajaran yang dilakukan sepenuhnya di tempat DU/DI. Pada umumnya perusahaan lebih memilih model Block Release karena dianggap paling efektif. Pengawasan dilakukan oleh Guru Pembimbing melalui kegiatan monitoring yang dilakukan secara berkala. Selain itu Pembimbing dari DU/DI juga akan memantau perkembangan peserta didik secara intensif. Persiapan lain yang dilakukan sekolah sebelum pelaksanaan Prakerin antra lain: 1) menentukan tempat prakerin bagi peserta didik; 2) melengkapi administrasi; 3) pembekalan baik peserta didik maupun guru pembimbing.

Demi kelancaran program prakerin yang akan dijalankan, maka harus dilaksanakan sesuai dengan prosedur. Prosedurnya antra lain analisa pada pencapaian kompetensi peserta didik, pemetaan tempat prakerin, penyusunan program, pelaksanaan serta pengawasan dan penilaian. Selain itu aspek penting untuk di laksanakan adalah penjadwalan, peserta prakerin, pembiayaan dan administrasi lain terkait program prakerin.

Pada penelitian ini mengunakan metode CIPP. Menurut Mirwati dkk (2015) evaluasi program merupakan suatu proses yag sistematis dalam mengumpulkan informasi, mengukur, menganalisis serta menginterpertasi informasi tersebut sebagai upaya untuk memperoleh gambaran suatu proses program dalam mencapai tujuan.Menurut Jaya (2018) Evaluasi merupakan salah satu rangkaian penting dalam siklus perencanaan dan pelaksanaan suatu program. Tanpa evaluasi tidak dapat dipastikan ketercapaian tujuan program. Sebaliknya, dengan melakukan evaluasi tingkat ketercapaian tujuan suatu program dapat diketahui. Gambaran tentang tingkat keberhasilan suatu program memiliki efek signifikan terhadap keputusan dan langkah strategis yang akan diambil. Menurut Bhakti (2017) Untuk mengetahui tercapai tidaknya tujuan khusus pembelajaran guru perlu mengadakan evaluasi model CIPP (Contexs, Input, Prosess, Product). Karena penilaian ini untuk mengetahui sejauh mana peserta didik telah menguasai tujuan khusus pembelajaran yang ingin dicapai oleh sebab itu seorang guru hendaknya secara terus menerus mengikuti hasil belajar yang telah dicapai oleh peserta didiknya. Informasi yang diperoleh dari evaluasi model CIPP ini merupakan umpan balik terhadap proses hasil belajar megajar yang telah dilaksanakan dan umpan balik ini akan menjadi tolok ukur untuk memperbaiki dan meningkatkan proses belajar mengajar selanjutnya. Mahmudi (2011) mengemukakan evaluasi pendidikan merupakan salah satu bentuk mekanisme sistem pendidikan yang bertujuan untuk meninjau ulang proses pendidikan yang telah dilaksanakan dalam beberapa kurun waktu tertentu. Tinjauan ulang tersebut dimaksudkan untuk memahami, menggali, serta mengkoreksi proses pendidikan tersebut sehingga akan diketahui celah-celah kekurangan yang harus diperbaiki dan ditutupi Menurut Muyana (2017) Model evaluasi CIPP menekankan evaluasi sebagai proses yang menyeluruh dalam sistem manajerial layanan informasi. Evaluasi yang baik seharusnya memiliki tujuan untuk memperbaiki bukan untuk membuktikan, meningkatkan akuntabilitas, serta pemahaman lebih terhadap suatu fenomena. Menurut Stufflebean (2003:2) menjelaskan evaluasi CIPP merupakan singkatan dari evaluasi konteks, Input, proses dan produk. Evaluasi konteks digunakan untuk menilai dan mengidentifikasi kebutuhan, masalah, dan peluang guna pengambilan keputusan. Evaluasi Input digunakan menilai kemungkinan pendekatan, rencana program, ketersediaan peralatan, dan kecukupan dan kebergunaan 
dana agar program dapat dilaksanakan. Evaluasi Proses adalah pelaksanaan dari rencana yang telah dibuat sebelunya. Selain itu evaluasi proses juga dipergunakan untuk membuat penfsiran hasil akhir program prakerin. Evaluasi Produk akan menemukan dan menilai hasil kegiatan secara keseluruhan. Hasil dari evaluasi produk akan difungsikan sebagai tolak ukur dari kegiatan yang telah berlangsung.

Penelitian yang dilakukan oleh Susanto Imam dengan judul evaluasi pelaksanaan praktek kerja industri (prakerin) pada mata diklat produkti di smk sunan giri menganti gersik penelitian yang dilakukan pada tahun 2015 ini bertujuan untuk melihat kesesuaian program prakerin dengan hasil yang dilaksanakan. Metode yang digunakan pada penelitian ini adalah deskriptif kualitatif. Hasil dari penelitian ini menunjukan bahwa adanya perubahan nilai dari sebelum dan sesudah melakukan prakerin. Dari hasil angket yang diberikan oleh siswa dan tempat DU/DI menunjukan perlu adanya evaluasi terhadap pembimbing guru prakerin. Ketika dilihat dari jumlah skor jawaban, jawaban masuk dalam kategori "sangat baik".

Penelitian yang dilakukan oleh Supadi (2017) dengan judul "evaluasi program praktek kerja industri di siswa sekolah menengah kerjurusan (SMK)". Penelitian yang bertujuan untuk mendeskripsikan konteks, input, proses dan produk dari program prakerin pada program keahlian Administrasi Perkantoran SMK BPS\&K II Bekasi. Metode penelitian yang digunakan adalah CIPP. Teknik pengumpulan data menggunakan observasi, angket dan wawancara. Hasil penelitian menunjukan bahwa pada variabel konteks tingkat pencapaian sebesar $85,16 \%$ dengan kategori baik. sedangkan pada aspek input sebesar $82,77 \%$ kategori baik. Pada asepek Proses sebesar 85,03\% dengan kategori baik. Terakhir pada aspek Produk sebesar 96\% dengan kategori sangat baik.

Dari kedua penelitian terdahulu memberikan gambaran bahwa metode CIPP sangat tepat untuk mengevaluasi program prakerin. Yang membedakan penelitian ini dengan penelitian sebelumnya adalah penelitian ini sampai pada tahap dampak dan keberlanjutan program.

Evaluasi yang dilakukan di SMK Saraswati Salatiga bertujuan untuk melihat sejauh mana efektivitas pelaksanaan program Prakerin yang dilaksanakan SMK Saraswati Salatiga. Evaluasi dilaksanakan menggunakan model CIPP dinama analisis dilakukan pada aspek context, input, process, dan product terhadap program Prakerin SMK Saraswati Salatiga. Evaluasi komponen Context meliputi kesesuaian pelaksanaan program dengan dasar hukum yang digunakan, kesesuaian antara tujuan program dengan visi dan misi, kesesuaian tujuan prakerin dengan kebutuhan akan kegiatan prakerin. Evaluasi komponen Input meliputi apakah program prakerin sudah terencana sebelumnya, apakah sudah dilakukan penjadwalan dalam melaksanakan program prakerin, apakah langkah-langkah program sudah ditetapkan, apakah sumber daya sudah mencukupi dari kebutuhan program, dan apakah tempat prakerin sudah sesuai dengan yang diharapkan dari sekolahan. Evaluasi komponen Process meliputi kesesuaian antara pelaksanaan prakerin dengan rencana program, dan dinamika permasalahan yang terjadi selama program dilaksanakan. Evaluasi Komponen Product meliputi sejauh mana tujuan program dapat tercapai, program apa yang tercapai dengan hasil tinggi dan apa yang tercapai dengan hasil rendah, bagaimana tingkat kepuasan pihak yang menjadi sasaran program, apa dampak positif dan negatif program, apa program perlu dilanjutkan, dilanjutkan dengan perbaikan, atau tidak dilanjutkan. Evaluasi yang dilakukan di SMK Saraswati Salatiga bertujuan untuk melihat sejauh mana efektivitas pelaksanaan program Prakerin yang dilaksanakan SMK Saraswati Salatiga. Evaluasi dilaksanakan menggunakan model CIPP dinama analisis dilakukan pada aspek context, input, process, dan product terhadap program Prakerin SMK Saraswati Salatiga. Evaluasi komponen Context meliputi kesesuaian pelaksanaan program dengan dasar hukum yang digunakan, kesesuaian antara tujuan program dengan visi dan misi, kesesuaian tujuan prakerin dengan kebutuhan akan kegiatan prakerin. Evaluasi komponen Input meliputi apakah program prakerin sudah terencana sebelumnya, apakah sudah dilakukan penjadwalan dalam melaksanakan program prakerin, apakah langkah-langkah program sudah ditetapkan, apakah sumber daya sudah mencukupi dari kebutuhan program, dan apakah tempat prakerin sudah sesuai dengan yang diharapkan dari sekolahan. Evaluasi komponen Process meliputi kesesuaian antara pelaksanaan prakerin dengan rencana program, dan dinamika permasalahan yang terjadi selama program dilaksanakan. Evaluasi Komponen Product meliputi sejauh mana tujuan program dapat tercapai, program apa yang tercapai dengan hasil tinggi dan apa yang tercapai dengan hasil rendah, bagaimana tingkat 
kepuasan pihak yang menjadi sasaran program, apa dampak positif dan negatif program, apa program perlu dilanjutkan, dilanjutkan dengan perbaikan, atau tidak dilanjutkan.

Berdasarkan wawancara dan data evaluasi yang dilakukan SMK Saraswati Salatiga menjelaskan bahwa masih ada beberapa masalah dalam pelaksanaan Program Prakerin. Masalah tersebut antara lain: 1) pelaksanaan prakerin dilaksanakan separu rombel selama 6 bulan, sehingga pelaksanaan dilakukan satu tahun penuhu; 2) masih ada siswa yang belum berangkat prakerin; 3) peserta didik gagal mengikuti Program Prakerin; 3) Masih terdapat Kecelakaan Kerja dan; Pola pelaksanaan Prakerin yang belum seragam.

\section{METODE}

Pada penelitian ini menggunakan pendekatan kualitatif. Moleong (2014: 6) menjelaskan penelitian kualitatif adalah penelitian yang bermaksud untuk memahami fenomena tentang apa yang dialami oleh subjek penelitian misalnya perilaku, cara deskripsi dalam bentuk kata-kata dan bahasa, pada suatu konteks khusus yang alamiah dan dengan menfaatkan berbagai metode alamiah. Kegiatan Praktek kerja Industri akan diteliti lebih dalam dan data akan diambil dari pengalaman dari pembimbing lapangan dan juga pembimbing dari sekolahan. Hasil penelitian dari evaluasi prakerin berupa perbandingan secara terukur dari fakta-fakta yang terjadi dilapangan. Data tersebut dapat digunakan oleh Kepala Sekolah dalam memperbaiki atau menyempurnakan kegiatan prakerin yang dilakukan oleh Sekolah.

Penelitian dilakukan di SMK Saraswati Salatiga.Waktu pelaksanaan prakerin pada bulan Maret sampai dengan Mei 2020. Sedangkan Yang menjadi subjek pada penelitian ini adalah Kepala SMK, Wakil Kurikulum, ketua Panitia Prakerin, Guru pembimbing, Peserta didik dan juga pihak industri yang menjadi mitra dengan sekolah. Penelitian dilakukan untuk mengevaluasi pelaksaaan program prakerin yang ada di SMK Saraswati Salatiga.

Teknikyang digunakan untuk mengumpulkan data adalah wawancara, Dokumentasi dan Observasi. Menurut Arikunto (2006:136) menjelaskan bawa metode pengumpulan data merupakan cara yang digunakan peneliti dalam mengumpulkan data penelitianya

Pada penelitian ini, metode yang digunakan adalah Context, Input, Process, Product (CIPP). Konteks penelitian ini adalah mengenai Visi, Misi, Tujuan Prakerin dan dasar pelaksanaan prorgam Prakeirn. Sedangkan aspek input pada penelitian ini adalah mengenai sumber daya yang digunakan seperti Perencanaan, Jadwal Pelaksanaan, Mekanisme dan penyesuaian tempat prakerin. Pada asepk pelaksaan akan melihat kesesuaian antara pelaksanaan dengan rencana yang telah dibuat. Sedangkan aspek Produk mengenai hasil Prakerin dan dampak program prakerin pada berbagai pihak seperti sekolah, peserta didik, dan Industri. untuk lebih jelasnya dapat dilihat pada tabel berikut:

Tabel 1. Tahap Evaluasi CIPP dalam Komponen Praktek Kerja Industri

\begin{tabular}{|c|c|c|c|c|}
\hline No. & $\begin{array}{l}\text { Tahap } \\
\text { Evaluasi }\end{array}$ & Aspek yang Diteliti & $\begin{array}{l}\text { Sumber } \\
\text { Data }\end{array}$ & $\begin{array}{c}\text { Teknik Pengumpulan } \\
\text { Data }\end{array}$ \\
\hline 1 & Context & $\begin{array}{ll}\text { Visi, Misi dan tujuan prakerin, dasar } \\
\text { hukum, kebutuhan siswa akan } \\
\text { prakerin. }\end{array}$ & $\begin{array}{l}\text { Wakil } \\
\text { humas, guru } \\
\text { pembimbing }\end{array}$ & $\begin{array}{c}\text { Wawancara dan studi } \\
\text { dokumentasi }\end{array}$ \\
\hline 2 & Input & $\begin{array}{l}\text { Perencanaan, jadwal pelaksanaan, } \\
\text { mekanisme, sumber daya manusia } \\
\text { yang terlibat, tempat pelaksanaan } \\
\text { prakerin. }\end{array}$ & Wakil humas & $\begin{array}{l}\text { Observasim } \\
\text { dokumentasi. } \\
\text { Wawancara }\end{array}$ \\
\hline 3 & Process & $\begin{array}{l}\text { Pelaksanaan prakerin membandingkan } \\
\text { perencanaan dan pelaksanaan } \\
\text { program, penemuan masalah. }\end{array}$ & $\begin{array}{l}\text { Guru } \\
\text { pembimbing, } \\
\text { humas, } \\
\text { siswa }\end{array}$ & $\begin{array}{c}\text { Wawancara, observasi, } \\
\text { dokumentasi }\end{array}$ \\
\hline 4 & Product & $\begin{array}{l}\text { Hasil atau dampak dari program } \\
\text { prakerin kepada siswa, guru } \\
\text { pembimbing, DU/DI }\end{array}$ & $\begin{array}{l}\text { Siswa, guru } \\
\text { pembimbing, } \\
\text { pembimbing } \\
\text { prakerin, } \\
\text { humas }\end{array}$ & $\begin{array}{c}\text { Wawancara, observasi, } \\
\text { kuisioner. }\end{array}$ \\
\hline
\end{tabular}


Untuk menjamin tingkat kebenaran data digunakan metode Triangulasi. Teknik penerapan triangulasi data pada penelitian ini adalah dengan cara membandingkan hasil wawancara ketua panitia prakerin dengan keterangan dari kepala sekolah, guru pembimbing, peserta didik dan pemilik industri.

Teknik analisa data yang digunakan adalah deskripsi pada kelompok tahapan evaluasi CIPP. Teknik yang digunakan adalah model Miles, Huberma dan Saldana (2014:31). analisis data dilakukan secara interaktif dan berlangsung secara terus menerus hingga datanya jenuh. Sebelum ditarik kesimpulan data disusun secara berurutan mulai dari konensasi data dan penyajian data.

\section{HASIL DAN PEMBAHASAN}

Dari aspek Konteks Program Prakerin DI SMK Saraswati Salatiga menggunakan Dasar Hukum yang kuat antara lain: UU No. 20 Tahun 2003 Tentang Sistem Pendidikan Nasional, PP No. 13 Tahun 2015 Tentang Standar Nasional Pendidikan, PP No 66 Tahun 2010 Tentang Pengelolaan dan Penyelenggaraan Pendidikan, PP RI No.41 Tahun 2015 Tentang Pembangunan Sumber Daya Industri, Perpres No. 8 Tahun 2012 Tentang kerangka Kualifikasi Nasional Indonesia (KKNI), Inpres No. 9 Tahun 2016 Tentang Revitalisasi Sekolah Menengah Kejuruan dalam Rangka Peningkatan Kualitas dan Daya Saing Sumber Daya Manusia Indonesia. Kemudian Tujaun pelaksanaan Prakerin sudah sesuai dengan Visi yaitu menjadi SMK yang terkemuka. Sedangkan Misi SMK Saraswati Salatiga adalah Menyelenggarakan pelayanan Pendidikan dan pelatihan secara Profesional untuk menghasilkan tamatan yang cerdas, terampil dan kompetitif. Sedangkan tujuan Program prakerin di SMK Saraswati Salatiga antra lain: 1) memberikan pengalaman kerja secara langsung kepada peserta didik agar meningkatkan mutu proses belajar dan hasil kerja; 2) menumuh kembangkan etos kerja bagi peserta didik agar siap memasuki dunia kerja; 3) memberi kesempatan peserta didik agar mendapatkan pengalam kerja yang sesuai dengan kompetensi keahliannya; 4) sebagai media akualisasi diri dari program pembelajaran yang didapat di sekolah.

Dari aspek input prakerin dimulai dari membuat RKAS yang disusun pada awal Semester pertama. Kemudian dari RKAS diturunkan menjadi jadwal pelaksanaan prakerin yaitu pada bulan September sampai dengan Januari. Terget program prakerin adalah peserta didik kelas II. SMK Saraswati Salatiga menggunakan model Block Release untuk pelaksanaannya. Model Block Release merupakan model pembelajaran secara penuh dilakukan di tempat industri. Mekanisme yang digunakan adalah; 1) Menentukan jadwal pelaksnaan Prakerin; 2) Mencari Industri sebagai tempat Prakerin; 3) Peserta didik diijinkan menentukan tempat prakerin atas persetujuan dari sekolah; 4) Serah terima peserta didik ke Industri; 5) Monitoring peserta didik di tempat prakerin; 6) Penarikan peserta didik dari industri; 7) Membuat laporan prakerin oleh peserta didik; 8) Ujian laporan prakerin oleh peserta didik. sedangakan anggaran pada program prakerin ditentukan dari RKAS Sekolah. Anggaran yang diajukan akan digunakan untuk membiayai kebutuhan prakerin, seperti pembekalan, penyerahan, monitoring, penarikan dan kebutuhan administrasi lainya. Terakhir dalam menentukan tempat prakerin Sekolahan akan membuat pertimbangan antara lain jumlah kariawan, pekerjaan yang cukup untuk peserta didik dan relevansi dengan kompetensi keahlian peserta didik, dengan pertimbangan geografis tempat prakerin.

Proses pelaksanaan prakerin di SMK Saraswati Salatiga dimulai dari rencana yang telah ditentukan. Jadwal prakerin dibuat berdasarkan kaleder akademik. Prinsipnya sebelum pelaksanaan program prakerin peserta didik belajar keterampilan sesuai kompetensi keahliannya. Jika peserta didik belum tuntas pada mata pelajaran tertentu merekan belum diijinkan mengikuti program prakerin. Kemudian pada saat prakerin guru pembimbing akan melakukan monitoring peserta didik di industri, waktunya adalah satu bulan sekalin. Monitoring dilakukan untuk melihat perkembangan yang dialami oleh peserta didik. Selain itu juga memberi penanganan secara dini jika terjadi permasalahan yang dialami peseta didik. Masalah yang terjadi dalam pelaksanaan prakerin di SMK Saraswati Salatiga adalah kedisiplinan siswa. Selain itu juga sering peserta didik mengambaikan K3. Dalam penanganan permasalahan yang dilakukan beberapa tahapan. Tahap pertama dalam penanganan permasalahan peserta didik adalah dengan memberi pendekatan secara mendalam tehadap permasalahan yang dialami. Jika pendekatan yang dilakukan oleh guru pembimbing tidak mampu memberikan perubahan positif, guru pembimbing akan memberikan tindakan yaitu penarikan kepada peserta didik. Setelah peserta didik ditarik dari industri, mereka akan dipindahkan pada 
industri yang memiliki kontroling lebih mudah. Sehingga guru pembimbing dapat memantau peserta didik lebih baik. Langkah terakhir jika tidak ada industri yang mau menerima peserta didik tersebut, mereka akan di tempatkan pada Unit Produksi yang dimiliki oleh sekolah.

Dari aspsek Produk kegiatan prakerin di SMK Saraswati Salatiga sudah dilaksanakan dengan baik. Hal tersebut terlihat banyak peserta didik yang diterima kerja diperusahaan mereka mengikuti program prakerin. Selain itu sering juga Industri meminta memperpanjang program prakerin peserta didik. Hal tersebut menjadi indikator bahwa Industri Puas akan kinerja peserta

\section{PENUTUP}

Berdasarkan hasil penelitian dan pembahasan mengenai Evaluasi Program Praktek Kerja Industri di SMK Saraswati Salatiga dengan menggunakan model CIPP dapat disimpulkan sebagai berikut: a) Aspek Konteks: visi dan misi telah dijabarkan dalam perumusan kompetensi lulusan yang tertuang dalam program kerja sekolah. Dalam penyusunan kurikulum SMK Saraswati telah melibatkan Industri sebagai mitras. Identifikasi kebutuhan dan peluang telah dilaksanakan namun dikarenakan keterbatasan tempat prakerin dan banyaknya peserta didik perlu dikembangkan lagi. Peserta prakerin adalah peserta didik kelas XI, yang pelaksanaanya di semester pertama; b) Aspek Input: Prakerin telah dilaksanakan sesuai dengan stragegi dan perencanaan yang telah dibuat. Prosedur penempatan peserta didik di industri, jadwal pelaksanaan program dan anggaran biaya suda dilaksanakan sesuai prosedur, dan sama dengan pedoman yang buat sebelumnya; c) Aspek Proses: Keseluruhan proses prakerin yaitu mencakup persiapan, monitoring oleh guru pembimbng ke lapangan. Dan juga kesiapan seluruhan perlengkapan yang dibutuhkan untuk kegiatan prakerin. Pada pelaksanaan prakerin ada faktor yang menjadi penghambat yaitu dari internal antara lain. Kedisiplinan, motivasi, kemampuan berfikir dan komunikasi peserta didik. Sedangkan yang menghambat dari faktor eksternal antara lain kurangnya kepercayan industri pada peserta didik. Selain itu rendahnya relevansi pekerjaan di industri dengan kompetensi keahlian peserta didik. Sedangkan yang menjadi faktor pendukung prakerin adalah adanya kerja sama dengan Industri yang mendukung penuh pembelajaran peserta didik selama berkerja disana. Fasilitas yang dimiliki oleh Industri yang lengkap juga menjadi faktor didik. selain kepuasan Industri kegiatan prakerin juga memiliki dampak yang didapatkan. Manfaat yang diperoleh bagi sekolah adalah lebih dikenal masyarakat. Hal tersebut secara tidak langsung memiliki relevansi dengan Visi SMK Saraswati Salatiga yaitu menjadi sekolahan yang terkemuka. Manfaat yang diperoleh peserta didik adalah peningkatan keterampilan sesuai dengan bidang kompetensinya. Selain itu juga menumbuh kembangakan rasa percaya diri. Sedangkan Sedangkan manfaat yang diperoleh DU/DI adalah meringankan bebannya sehingga pekerjaan lebih cepat dikerjakan.

pendukung kegiatan prakerin; d) Aspek Produk: Untuk melihat produk prakerin dapat dilihat dari kemampuan peserta didik selama proses belajar di tempat prakerin. Berdasarkan nilai yang didapat Industri yang diberikan kepada siswa rata-rata di atasa KKM yaitu 75 . Manfaat yang diperoleh bagi sekolahan adalah lebih mudah dalam menyusun strategi agar perbandingan rasio kelulusan siap kerja lebih tinggi. Sedangakn utuk perserta didik program prakerin sangat membantu meningkatkan kompetensi keahlian, meningkatkan kepercayaan diri dan menambah pengalaman. Bagi Industri manfaat program prakerin adalah meringankan perkejaan mereka.

Yang menjadi saran dari penelitian ini adalah sebagai berikut: Dalam melakukan monitoring guru pembimbing harus lebih maksimal sehingga dapat mengontrol peserta didik lebih baik lagi. Memberik peraturan yang lebih agar peserta didik lebih disiplin ketika bekerja di tempat Industri.Pemetaan industri dilakukan lebih mendalam agar relevansi kompetensi keahlian pesert didik dengan apa yang dikerjakan di industri lebih tinggi. Penelitian yang dilakukan di SMK Saraswati Salatiga menggunakan metode CIPP untuk mengevaluasi program Prakerin. Hasil dari penelitian menunjukan masih adanya kekurangan pada unsur dampak prakerin yang masih dapat dilakukan evaluasi lanjutan dengan tujuan memperdalam hasil evaluasi dampak prakerin.

\section{DAFTAR PUSTAKA}

Arikunto, Suharsini. 2006. Dasar-Dasar Evaluasi Pendidikan. Jakarta: Bumi Aksara

Arikunto, Suharsimi. 2008. Evaluasi Program Pendidikan. Jakarta: Bumi Aksara 
Arikunto, Suharsimi dan Cepi Safruddin AJ. 2010. Evaluasi Program Pendidikan. Jakarta: Bumi Aksara.

Bhakti, Yoga Budi. 2017. Evaluasi Program Model CIPP Pada Proses Pembelajaran IPA. JIPFRI: Jurnal Inovasi Pendidikan Fisika dan Riset Ilmiah Vol. 1 No. 2 Hal. 75-82. Tersedia Pada: https://journal.stkipnurulhuda.ac.id/ind ex.php/JIPFRI/article/view/109.

Dikmenjur. (2008). Kurikulum SMK

Farida Yusuf. 2000. Evaluasi Proggram. Jakarta: PT. Rineka Cipta

Hamalik, Oemar. (2001). Proses Belajar Mengajar. Jakarta: Bumi Aksara

Hamalik, Oemar, 2007. Manajemen Pengembangan Kurikulum, Bandung: PT. Remaja Rosda Karya

Hamalik, Oemar. 2008. Kurikulum dan Pembelajaran. Jakarta: Bumi Aksara

Jaya, Petrus Redy Partus, Felisitas Ndeot. 2018. Penerapan Model Evaluasi CIPP dalam Mengevaluasi Program Layanan PAUD Holistik Integratif. Pernik Jurnal PAUD, Vol 1 No.1 Hal. 10-25. Tersedia Pada: https://obsesi.or.id/index.php/obsesi/ar ticle/view/200.

J.Moleong, Lexy.2014. Metode Penelitian Kualitatif, Edisi Revisi. PT Remaja Rosdakarya, Bandung.

Mahmudi. (2011). CIPP: Suatu Model Evaluasi Program Pendidikan. Jurnal At-Ta'dib, 6 (1).

Matondang, Zulkifli. Evaluasi Hasil Belajar. Yayasan Kita Menulis: Medan

Miles,M.B, Huberman,A.M, dan Saldana,J. 2014. Qualitative Data Analysis, A Methods Sourcebook, Edition 3. USA: Sage Publications. Terjemahan Tjetjep Rohindi Rohidi, UI-Press.

Mirwati Sidin Ali Jikebet Saludung. 2015. Evaluasi Program Pembelajaran Kimia pada SMA Negeri 3 Watansoppeng. Jurnal Penelitian dan Evaluasi Pendidikan Volume 1, No. 1 Hal. 1-9. Tersedia Pada: http://ojs.unm.ac.id/assesment/article/ download/1781/pdf_8.

Muyana, Siti. 2017. Context Input Process Product (CIPP): Model Evaluasi Layanan Informasi. Prosiding Seminar Bimbingan dan Konseling, Vol. 1, No. 1, 2017, hlm. 342-347. Tersedia Pada: http://pasca.um.ac.id/conferences/inde x.php/snbk.

Peraturan Pemerintah No. 29 Tahun 1990 Tentang Pendidikan Menengah

Rukajat Ajat. 2018. Pendekatan Penelitian Kualitatif (Qualitative Research Approach): Deepublish

Spaulding T. Dean. 2013. Program Evaluation In Practice Core Concept And Examples For Discussion and Analaysis.San Francisco: Jossey Bass

Stufflebeam, D.L. (2003). The CIPP model for evaluation,the article presented at the 2003 annual conference of the Oregon program evaluators network (OPEN) 3 Oktober 2003. Diambil pada tanggal 25 Maret 2020, dari http://www.wmich.edu/evalctr/cippmod el.

Stufflebeam. 2017.The CIPP Evaluation Model. New York: kluwer

Sugiyono. 2010. Metode Penelitian Pendidikan Pendekatan Kuantitatif, Kualitatif dan R\&D. Bandung: Alfabeta

Sutama. 2012. Metode Penelitian Pendidikan Kuantitatif, Kualitatif, PTK, R\&D. Kartasura: Fairuz Media

Wardiman Djojonegoro. 1998. Pengembangan Sumber Daya Manusia Melalui SMK. Jakarta: Jayakarta Agung Offset

Wirawan. 2011. Evaluasi Teori, Model, Standar, Aplikasi, dan Profesi, Jakarta: PT. Raja Grafindo Persada. 